\title{
FOREIGN DIRECT INVESTMENT IN THE KINGDOM OF SAUDI ARABIA: A DIAGNOSTIC ANALYSIS
}

\author{
Luluwa Juma ${ }^{* 1} \bowtie$ (iD), Hannan Alkharoossi ${ }^{2}$, Manuel Fernandez ${ }^{3}$ \\ ${ }^{1}$ School of Business, Skyline University College, Sharjah, UAE.
}
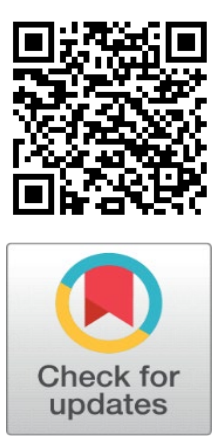

Received 6 August 2021

Accepted 18 August 2021

Published 31 August 2021

\section{CorrespondingAuthor}

Manuel Fernandez,

mfernandez@skylineuniversity.ac.ae

DOI

10.29121/granthaalayah.v9.i8.2021. 4193

Funding: This research received no specific grant from any funding agency in the public, commercial, or not-for-profit sectors.

Copyright: (C) 2021 The Author(s). This is an open access article distributed under the terms of the Creative Commons Attribution License, which permits unrestricted use, distribution, and reproduction in any medium, provided the original author and source are credited.

\section{ABSTRACT}

This study aims to identify the status of Saudi Arabia as a destination for FDI, the factors that attract FDI into Saudi Arabia, and the factors that hinder the flow of FDI into Saudi Arabia. The study covers a period of five years from 2015 to 2019. The study analysis various determinants of FDI: market size, infrastructure, technology adoption, innovation friendliness, productive and diversified labour force, financial infrastructure, taxation, political risk, corruption, and ease of doing business. The study finds that several factors like market size, well-developed infrastructure, a higher degree of technology adoption, innovation-friendliness, the banking system that is well-capitalized and liquid, low corporate taxes, political stability, low transfer risk, low expropriation risk, low levels of corruption, and a stable currency make Saudi Arabia an attractive destination for FDI. At the same time, the low labour market efficiency and the low ranking in ease of doing business makes it less attractive to FDI.

Keywords: Investment Decision, MNC, Investor-Friendly Destination

\section{INTRODUCTION}

In this interconnected, interdependent world, there is a great flow of funds among countries, money flowing to destinations that offer higher returns, are more investor-friendly, and are relatively less risky. Different countries have different characteristics that attract different investors differently at different times. Several studies have been carried out to understand the different factors attracting investments, and the results of these studies have highlighted a number of factors. Foreign Direct Investment (FDI) is the investment made by a company in the investor country into a foreign host country. It can take the form of acquiring already existing host firms, establishing new companies in the host country, or entering into a joint venture with an existing host firm. The importance of FDI is growing because of the beneficial impact on both the host country's economy and a firm's return on investment and the opportunity for geographical diversifications, which may help evade even the systematic risk.

The inflow of FDI gives developing countries access to capital that would otherwise be unavailable, as Multinational Corporations (MNCs) often have privileged access to capital from the international banking sectors and international investors at competitive rates. Likewise, FDI provides muchneeded foreign exchange and helps adjust some of the macroeconomic imbalances in developing countries. Many countries in Asia, Africa, and the Middle East are in the growth mode, but the resources available for development are limited and insufficient; hence, all these nations compete to make the 
investment climate better and present themselves as the best FDI-friendly destination.

Saudi Arabia, officially the Kingdom of Saudi Arabia, is a country in Western Asia. Saudi Arabia is the largest country in the Middle East and the second-largest country in the Arab world. The population of Saudi Arabia is estimated to be approximately 35 million. Its population is also relatively young, with a median age of 31.8 years; only $3 \%$ is over 65 . A large fraction (above $30 \%$ ) are foreign nationals, approximately 10.5 million. Saudi Arabia is the largest economy in the Middle East and the 18th largest in the world. Saudi Arabia has the world's second-largest proven petroleum reserves, and the country is the largest exporter of petroleum. Saudi Arabia, which has $17 \%$ of proven global petroleum reserves, is vigorously pursuing a vision to diversify its economy by boosting manufacturing, services, and tourism. Vision 2030 was implemented by the Government of Saudi Arabia, which sets out a plan for Saudi Arabia's future to reduce its dependence on oil and raise private sector participation. The Vision aims to achieve long-term objectives, like raising the quantity and level of availability work and better opportunities, particularly in the private sector, ensuring sustainable jobs for the Saudi citizens, and reducing the unemployment rate for Saudi residents. One of the primary ways to achieve this is by attracting FDI into the Kingdom. Attracting FDI requires the easing of restrictions and a big departure from previous practices. The country's leadership clearly understands that what worked earlier may not work in the future and are in the process of initiating several reforms to contain this.

The main objectives of this study are to find out the status of Saudi Arabia as a destination for FDI, the factors that attract FDI into Saudi Arabia and how these can be enhanced, and the factors that hinder the flow of FDI into Saudi Arabia, and how these can be reduced. The study's findings would help the investors arrive at a better decision regarding FDI into Saudi Arabia and similarly help the regulators and other stakeholders formulate appropriate policies and take necessary steps to enhance the FDI attractiveness of Saudi Arabia. This paper is organized as follows: Section 2 presents a related literature review. Section 3 states the methodology. Section 4 focuses on analysis and discussions, and Section 5 concludes the paper.

\section{LITERATURE REVIEW}

Foreign direct investment is widely perceived as a powerful development engine for many receiving (host) countries. The study by Osunkwo (2020) attempted to estimate the impact of FDI on the Economic Growth of Nigeria for the period 1980-2018, and it was found that FDI has a positive and significant impact on Gross Domestic Product (GDP). Virtually all countries actively seek to attract FDI because of its expected favourable effect on income generation from capital inflows, advanced technology, management skills, and market know-how Cho (2003).

A large number of studies on FDI have been conducted in different parts of the world, and a majority of these studies have been mainly concerned with various host-country determinants that are associated with attracting firms to specific locations Balasubramanyam et al. (1996), Alguacil et al. (2002), Liu et al. (2002). The most frequently investigated determinants include market size, economic stability, government policies, entry barriers, degree of openness, human capital, cost of production, wage rate, per capita income, exchange rate, infrastructure, geographical location, cost of capital, quality of institutions, technologyfriendliness, connectivity, etc. Loree and Guisinger (1995), Reiljan (2003), Fernandez et al. (2020), Alshamlan et al. (2021), Al Hosani et al. (2021), Alnuaimi et al. (2021). 
The presentation of the literature review is sequenced in such a manner that the literature relating to market size is presented first, followed by literature relating to other factors.

Market size is expected to have a positive relationship with FDI. Marketoriented FDI aims to set up enterprises to supply goods and services to the local market. The general inference is that host countries with larger market sizes, faster economic growth, and a higher degree of economic development will provide more and better opportunities for these industries to exploit their ownership advantages and, therefore, will attract more market-oriented FDI OECD (2000). Several studies such as that of Schmitz and Bieri (1972), Dunning (1980), Lunn (1980), Kravis and Lipesey (1982), Nigh (1985), Culem (1988), and Boateng et al. (2015) gauged that high rate of FDI is highly associated with a lower cost of production and enormous potential demand, which is further supported by the findings of the studies of Tsai (1994), Billington (1999), and Pistoresi (2000), that indicated that market size has positive effects on the inflow of FDI. The study by Makki et al. (2004) on the US food processing industry found that market size, per-capita income, and openness significantly affected the US food processing firms' decisions to invest abroad. The study by Reiljan (2003) of foreign direct investment determinants in Estonia found that most foreign investors in Estonia have a market-seeking nature. Thus, one may presume that large host countries with high growth rates and higher per capita income attract higher foreign direct investment due to greater potential demand.

Political stability and reliability determine the FDI inflows. MNCs prefer a stable government so that their investment is protected. Political instability may be in the form of the government's negative attitude towards MNCs, non-allowance of fund transfer, currency convertibility, war, bureaucracy, and corruption. The study by Root and Ahmed (1979), and Schneider and Frey (1985), looking at aggregate investment flows into developing economies, found that political instability significantly affects FDI inflows.

The study by Bouchoucha and Benammou (2020) examined the effect of governance on the attractiveness of FDI through a sample of 41 African countries to identify the institutional quality aspects that affect the attractiveness of FDI in African countries, using both the static panel data approach and the dynamic panel approach. The empirical results showed that the attractiveness of FDI to African countries is positively correlated with the control of corruption, the effectiveness of governments, the quality of regulation, and the voice and accountability.

Tax policies, including corporate and personal tax rates, influence inward FDI. Hajkova et al. (2006) explored the impact of taxation on FDI while controlling several policy and non-policy factors and found that taxation and the business environment are the main drivers of FDI in OECD (Organization for Economic Cooperation and Development) countries. Mutti and Grubert (2004) examined empirical asymmetries associated with the effects of taxation on foreign operations by the U.S. MNEs and validated that the tax rate in the host country can have a negative effect on subsidiary profit. Thus, countries with low tax rates are preferred by international investors.

According to Milner (2013), the presence of a productive labour force is one of the determinants that influence the scope of FDI in a country. Moreover, Cheap labour with more skills attracts foreign investors, as seen in Asian countries De Mello (1997).

Numerous studies have been conducted on FDI in different parts of the world, but most have been focusing only on a few of the determinants of the FDI. Moreover, studies focusing on Saudi Arabia are very few and are constrained by focusing only 
on a few factors. Hence, this study is undertaken to analyze the FDI environment in Saudi Arabia from a holistic perspective. Although FDI has innumerable effects on the economy of host countries and most countries are trying hard to attract FDI, the inflow of FDI continues to be uneven, with some countries getting the lion's share and others barely getting any.

\section{METHODOLOGY}

The main objectives of this study are to find out the status of Saudi Arabia as a destination for FDI, the factors that attract FDI into Saudi Arabia and how these can be enhanced, and the factors that hinder the flow of FDI into Saudi Arabia, and how these can be reduced. The study is solely based on secondary data collected from local, regional, and international agencies like the Government of Saudi Arabia, Saudi Central Bank, World Economic Forum, International Monetary Fund, Transparency International, World Bank Group, United Nations, and various publications of the statistical departments, governments, and the press. The study covers a period of five years from 2015 to 2019. Data relating to 2020 are excluded from this study as it was an abnormal year due to the Covid-19 pandemic. The collected data are tabulated, and a time series analysis is carried out using the global rankings to identify the various parameters that strengthen or weaken the FDIattractiveness of Saudi Arabia.

\section{ANALYSIS AND DISCUSSIONS}

The Global Competitiveness Report 2019 assesses the competitiveness landscape of 141 economies, providing insight into the drivers of their productivity and prosperity. These 141 economies account for $99 \%$ of the world's GDP. The competitiveness ranking is based on indicators organized into 12 pillars: Institutions; Infrastructure; ICT adoption; Macroeconomic stability; Health; Skills; Product market; Labour market; Financial system; Market size; Business dynamism; and Innovation capability. Each indicator or 'pillar' uses a scale from 0 to 100 to show how close an economy is to the ideal state or frontier of competitiveness in that area Global Competitiveness Report (2019). The Report series remains the most comprehensive assessment of national competitiveness worldwide. Table 1 presents the year-wise ranking of Saudi Arabia by global competitiveness index for 2015 to 2019.

\begin{tabular}{|ccccccc|}
\hline Table 1 Global Competitiveness Index: Ranking of Saudi Arabia & $\mathbf{2 0 1 5}$ to 2019 \\
\hline Year & $\mathbf{2 0 1 5}$ & $\mathbf{2 0 1 6}$ & $\mathbf{2 0 1 7}$ & $\mathbf{2 0 1 8}$ & $\mathbf{2 0 1 9}$ \\
\hline Global Rank & 25 & 29 & 30 & 39 & 36 \\
\hline
\end{tabular}

Source: Compiled from World Economic Forum, Global Competitiveness Reports from 2015 to 2019

The Global Competitiveness Reports show that the position of Saudi Arabia is declining during the recent past; however, in 2019, rank has improved marginally. A factor-wise analysis is made to ascertain the role played by each of them in attracting FDI into Saudi Arabia.

\subsection{MARKET SIZE}

Market size, growth in market size, and market efficiency are important determinants of FDI. The market size and the growth prospects of the host country's 
market are important pull factors and are positively related to the level of FDI flows Chandalert (2000). A huge market size allows the attainment of economies of scale, and transaction costs are lower in countries with higher levels of economic development Caves (1971), Zhao and Zhu (2000). A larger population means a better domestic market that can consume goods and services provided by investors. Saudi Arabia is the largest country in the GCC, with a population of 35 million, and the population is expected to grow to 39 million by 2030. It is the largest retail market in the GCC. Table 2 gives the global ranking for Saudi Arabia on the market size from 2015 to 2019.

Table 2 Market Size: Global Competitiveness Index Ranking of Saudi Arabia - 2015 to 2019

\begin{tabular}{cccccc}
\hline Year & $\mathbf{2 0 1 5}$ & $\mathbf{2 0 1 6}$ & $\mathbf{2 0 1 7}$ & $\mathbf{2 0 1 8}$ & $\mathbf{2 0 1 9}$ \\
$\begin{array}{c}\text { Global } \\
\text { Rank }\end{array}$ & 17 & 14 & 15 & 17 & 17 \\
\hline
\end{tabular}

Source: Compiled from Global competitiveness reports from 2015 to 2019

The position of Saudi Arabia is observed to vary from rank 14 to 17 but is mostly ranked at 17 . Nevertheless, Saudi Arabia has the largest market size among the GCC countries, which is a factor that attracts MNCs looking for scale.

\subsection{INFRASTRUCTURE}

Infrastructure is a major determinant of FDI. Excellent infrastructure plays a major role in the productivity and profitability of MNCs, and thus, their decision about FDI location. Table 3 gives the global ranking of Saudi Arabia for the period 2015 to 2019 based on road connectivity, quality of road infrastructure, railroad density, the efficiency of train services, airport connectivity, the efficiency of air transport services, liner shipping connectivity, the efficiency of seaport services, utility infrastructure, electricity access, electricity supply quality, exposure to unsafe drinking water and reliability of water supply.

Table 3 Infrastructure: Global Competitiveness Index Ranking of Saudi Arabia - 2015 to 2019

\begin{tabular}{cccccc}
\hline Year & $\mathbf{2 0 1 5}$ & $\mathbf{2 0 1 6}$ & $\mathbf{2 0 1 7}$ & $\mathbf{2 0 1 8}$ & $\mathbf{2 0 1 9}$ \\
$\begin{array}{c}\text { Global } \\
\text { Rank }\end{array}$ & 30 & 31 & 29 & 40 & 34 \\
\hline
\end{tabular}

Source: Compiled from Global competitiveness reports from 2015 to 2019

Infrastructure is vital for the long-term growth and competitiveness of emerging economies. It helps create jobs, improves standards of living, and reduces the cost of doing business. The Government is continuously investing in infrastructure projects with the intent of time-bound creation of world-class infrastructure in the country. Despite all these, the global ranking for Saudi Arabia was as low as 40 in 2018, even though it improved to 34 in 2019, demanding more infrastructure developments to make it more attractive to international investors. 


\subsection{TECHNOLOGY ADOPTION AND INNOVATION}

Technology is an important consideration made by foreign investors because it determines the scope of operational efficiency. The lack of efficient technology systems implies that operations would be slow and costly from an investment perspective. Thus, there will be a need to choose destinations with a higher level of technology adoption. Today technology is the cornerstone of the economic and social development strategies and plans adopted by the world's advanced economies. Table 4 gives the ranking for Saudi Arabia on Information and Communication Technology (ICT) adoption from 2015 to 2019 based on mobilecellular telephone subscriptions, mobile-broadband subscriptions, fixed broadband internet subscriptions, fibre internet subscriptions, and internet users.

Table 4 ICT Adoption: Global Competitiveness Index Ranking of Saudi Arabia - 2015 to 2019

\begin{tabular}{cccccc} 
Year & $\mathbf{2 0 1 5}$ & $\mathbf{2 0 1 6}$ & $\mathbf{2 0 1 7}$ & $\mathbf{2 0 1 8}$ & $\mathbf{2 0 1 9}$ \\
$\begin{array}{c}\text { Global } \\
\text { Rank }\end{array}$ & 42 & 41 & 44 & 54 & 38 \\
\hline
\end{tabular}

Source: Compiled from Global competitiveness reports from 2015 to 2019

ICT adoption is improving in Saudi Arabia and globally is ranked 38 in 2019, showing that it is relatively better. It is noteworthy that most of the other GCC nations have a high degree of technology adoption.

Innovation is the key to success and cooperation among individuals and government entities in developing solutions, and future foresight plays an accelerating role in this innovation and thus improves the country and society. Table 5 gives the ranking for Saudi Arabia on innovation friendliness from 2015 to 2019 based on diversity of the workforce, state of cluster development, international co-invention, multi-stakeholder collaboration, scientific publications, patent applications, R\&D expenditures, prominence of research institutions, buyer sophistication, and applications made for trademark.

Table 5 Innovation Capacity: Global Competitiveness Index Ranking of Saudi Arabia - 2015 to 2019

\begin{tabular}{cccccc}
\hline Year & $\mathbf{2 0 1 5}$ & $\mathbf{2 0 1 6}$ & $\mathbf{2 0 1 7}$ & $\mathbf{2 0 1 8}$ & $\mathbf{2 0 1 9}$ \\
Global & 34 & 42 & 40 & 41 & 36 \\
Rank & & & & & \\
\hline
\end{tabular}

Source: Compiled from Global competitiveness reports from 2015 to 2019

In innovation friendliness, the position shows a marginal improvement and is relatively in a good position with the global rank of 36 in 2019. However, Saudi Arabia requires more investments and more friendly policies to enhance technology adoption and innovations to stay competitive and become more attractive to FDI.

\subsection{PRODUCTIVE AND DIVERSIFIED LABOUR FORCE}

When international investors look for an investment destination, considerations about the skilled nature of the labour force are a matter of priority that determines their scope of success in a country Brakman and Garretsen (2008). A probe is made to understand the labour market efficiency. Table 6 gives the 
ranking for Saudi Arabia on labour market efficiency from 2015 to 2019 based on cooperation in labour-employer relations, the flexibility of wage determination, hiring and firing practices, redundancy costs, active labour market policies, workers' rights, ease of hiring foreign labour, internal labour mobility, the effect of taxation on incentives to work, pay and productivity, reliance on professional management, country capacity to retain talent, country capacity to attract talent and the ratio of women in the labour force.

\begin{tabular}{|c|c|c|c|c|c|}
\hline \multicolumn{6}{|c|}{$\begin{array}{l}\text { Table } 6 \text { Labour Market Efficiency: Global Competitiveness Index Ranking o } \\
\text { Saudi Arabia - } 2015 \text { to } 2019\end{array}$} \\
\hline Year & 2015 & 2016 & 2017 & 2018 & 2019 \\
\hline $\begin{array}{l}\text { Global } \\
\text { Rank }\end{array}$ & 60 & 65 & 80 & 102 & 89 \\
\hline
\end{tabular}

Source: Compiled from Global competitiveness reports from 2015 to 2019

During the period of study, Saudi Arabia's position had been declining; although it increased to rank 89 in 2019, which is a good sign, more efforts are required to make the country attractive. The positive side is the large young population; $65 \%$ of the Saudi population is aged under 35.

\subsection{FINANCIAL INFRASTRUCTURE}

Financial institutions with sufficient liquidity and transparency to grant quick loans at competitive rates are an important determinant. The banking system is well-capitalized and liquid. Table 7 gives the ranking for the financial system of Saudi Arabia from 2015 to 2019 based on the availability of domestic credit to the private sector, financing of SMEs, venture capital availability, market capitalization, insurance premium, soundness of banks, non-performing loans as a percentage of loan portfolio value, credit gap and banks' regulatory capital ratio.

Table 7 Financial System: Global Competitiveness Index Ranking of Saudi Arabia - 2015 to 2019

\begin{tabular}{cccccc} 
Year & $\mathbf{2 0 1 5}$ & $\mathbf{2 0 1 6}$ & $\mathbf{2 0 1 7}$ & $\mathbf{2 0 1 8}$ & $\mathbf{2 0 1 9}$ \\
Global & 41 & 47 & 56 & 45 & 38 \\
Rank & & & & & \\
\hline
\end{tabular}

Source: Compiled from Global competitiveness reports from 2015 to 2019

The position of Saudi Arabia is showing signs of improvement since 2018, but more attention from the concerned regulators and operators are necessary for boosting the efficiency of the financial system. A modernized technology-driven financial system is the need of the hour. Today, we are in a world where payments can be sent with a click of a button from the most basic cell phone. Countries must have financial sectors that ensure stability while offering deep, well-regulated markets and being agile enough to respond to rapid innovation in the industry.

\subsection{TAX RATES}

Lower tax will give corporates and individuals more after-tax income that could enhance the wealth of the corporates, and individuals could use it to buy more goods and services or save. Investors prefer lower-tax locations to locate or relocate their 
businesses. In Saudi, the rate on taxpayers in the exploitation of the natural gas sector is $20 \%$, and the rate on those producing oil and hydrocarbons ranges from $50 \%$ - 85\% depending on capital investment in Saudi. Remittance of profits abroad is considered deemed dividends subject to $5 \%$ withholding tax. Thus, the tax rate for the MNCs would depend on the sector they propose to operate. There is no individual income tax in Saudi Arabia.

\subsection{POLITICAL RISK}

MNCs usually assess political risk before investing in any country. There are many forms of political risks, but the extreme form is the possibility that the host country will take over a subsidiary. However, this form of political risk is extreme and not very common in today's global world. The more common forms of political risk include the negative attitude of the host government to MNCs, blockage of fund transfer, currency inconvertibility, war, bureaucracy, and corruption. The Credendo Group provides business and economic data for 200 countries and has classified country risk under different indicators like political risk short term, political risk medium/long term, special transactions risk, transfer risk, expropriation risk, and political violence risk; under each of these indicator's countries are classified into seven categories: from 1 (low risk) to 7 (high risk); among them, those related to Direct Investments are queried into slightly.

\subsubsection{TRANSFER RISK}

The currency inconvertibility and transfer restriction risk refer to the inability to convert and transfer out of the host country any funds related to the investment. Table 8 gives the ranking for the period 2015 to 2019.

Table 8 Transfer Risk: Credendo Group Index Ranking of Saudi Arabia - 2015 to 2019

\begin{tabular}{ccccccc} 
Year & $\mathbf{2 0 1 5}$ & $\mathbf{2 0 1 6}$ & $\mathbf{2 0 1 7}$ & $\mathbf{2 0 1 8}$ & $\mathbf{2 0 1 9}$ & Average \\
$\begin{array}{c}\text { Global } \\
\text { Rank }\end{array}$ & 2 & 3 & 3 & 3 & 3 & 2.8 \\
\hline
\end{tabular}

Source: Compiled from Credendo Group index reports 2015 to 2019

The average value for Saudi Arabia during the period of study was 2.8, which indicates that currency inconvertibility and transfer restriction risk is low.

\subsubsection{EXPROPRIATION RISK}

The risk of expropriation encompasses all discriminatory measures taken by a host government which deprive the investor of its investment without any adequate compensation; and also includes events of the embargo, change of (legal) regime and denial of justice, and the probability of a negative change in attitude towards foreign investments. Table 9 gives the expropriation risk ranking for the period 2015 to 2019. 


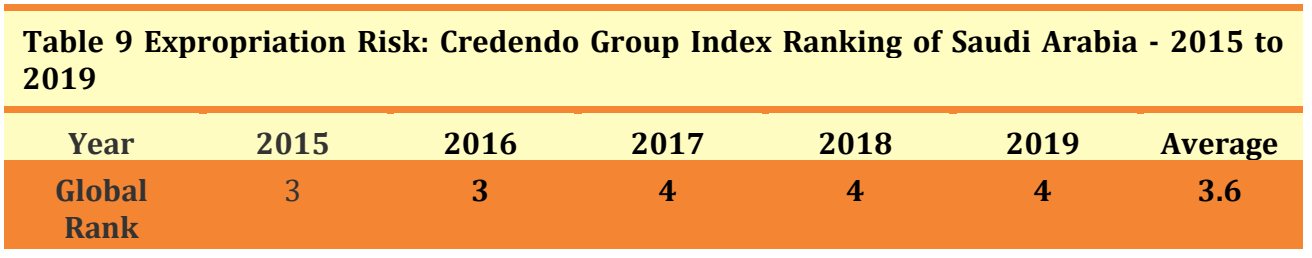

Source: Compiled from Credendo Group index reports 2015 to 2019

The average value for Saudi Arabia during the period of study is 3.6, which is low. All the GCC nations have low expropriation risk. To date, there had been no major political unrest in Saudi Arabia. One does not expect things to go wrong in the near future because of its rulers' strong political will and farsightedness in formulating strategies for the country's growth and wellbeing of the citizens and residents.

\subsubsection{CORRUPTION}

Corruption distorts competition and investment and hinders free and fair trade. Corruption erodes trust, weakens democracy, hampers economic development, and further exacerbates inequality, poverty, social division, and the environmental crisis. When the corruption level is sufficiently high, no investment will take place. Transparency International has published the Corruption Perceptions Index (CPI) since 1995, annually ranking countries by their perceived levels of corruption, as determined by expert assessments and opinion surveys. The CPI generally defines corruption as 'the misuse of public power for private benefit.' Table 10 displays the ranks assigned to Saudi Arabia from 2015 to 2019.

\begin{tabular}{|c|c|c|c|c|c|}
\hline Year & 2015 & 2016 & 2017 & 2018 & 2019 \\
\hline $\begin{array}{c}\text { Global } \\
\text { Rank }\end{array}$ & 48 & 62 & 57 & 58 & 51 \\
\hline
\end{tabular}

When the corruption level is sufficiently high, no investment will take place. Saudi Arabia is a low corrupt country in the Arab world. The international investors can be sure that they will get a warm welcome, their funds will not be blocked, enjoy easy convertibility, the least bureaucracy bottlenecks, and the lowest corruption.

\subsection{STABLE CURRENCY}

The volatility of the exchange rates influences the flow of FDI. Investors prefer a stable and less volatile currency, which ensures that their profitability is least affected by the vagaries of exchange rate fluctuations. They need not spend their time and money managing the forex risk. Since June 1986, the currency of Saudi Arabia is pegged to the US dollar. Hence the investors are assured an exchange rate of USD $=3.75$ Saudi Riyal. This pegged exchange rate is an important attraction for the inflow of FDI into this country. 


\subsection{EASE OF DOING BUSINESS}

The World Bank Group's Doing Business Report ranks economies based on their ease of doing business. These reports provide quantitative indicators on regulation for starting a business, dealing with construction permits, getting electricity, registering property, getting credit, protecting minority investors, paying taxes, trading across borders, enforcing contracts, and resolving insolvency. A high ease of doing business ranking means the regulatory environment is more conducive to the starting and operation of a local firm. Table 11 gives the ranking for Saudi Arabia from 2015 to 2019.

Table 11 Ease of Doing Business: Ranking of Saudi Arabia - 2015 - 2019

\begin{tabular}{cccccc}
\hline Year & $\mathbf{2 0 1 5}$ & $\mathbf{2 0 1 6}$ & $\mathbf{2 0 1 7}$ & $\mathbf{2 0 1 8}$ & $\mathbf{2 0 1 9}$ \\
$\begin{array}{c}\text { Global } \\
\text { Rank }\end{array}$ & 49 & 82 & 94 & 92 & 92 \\
\hline
\end{tabular}

Source: Compiled from the Doing Business Report 2015 to 2019

Doing Business data show that Saudi Arabia has to improve on many parameters in order to attract international investments. The current government policies and strategies are in this direction. In November 2020, Saudi Arabia announced sweeping labour reforms to improve the work environment and make the country attractive to the international workforce. The new regulations, which apply to all private-sector employees except domestic workers, will permit free mobility of the workforce, allowing the private sector to hunt and source talented workers from within the country. This will reduce headhunting costs, cut hiring time, boost the country's competitiveness, and make the country attractive to the talented workforce from home and abroad.

The reform also has done away with the contentious practice of employees seeking approval from employers before travelling outside Saudi Arabia. Now employees can apply online for exit and re-entry permits through the government portal, and employers will be notified electronically. Similarly, expatriate workers will be able to leave the country after the end of the employment contract without their employer's consent. The employer, however, will be notified electronically of their departure.

As part of the new vision, the Kingdom is becoming more liberal and restrictions imposed on cinemas, women driving, and a host of other social activities are lifted. Now shops and commercial establishments keep shops open and pursue commercial and economic activities throughout working hours, receiving shoppers and customers. Today, with the receding influences of the once-dominant Saudi Commission for the Promotion of Virtue and Prevention of Vice (CPVPV) or religious police, Saudi Arabia has become a more viable place to do business.

\section{CONCLUSION}

Saudi Arabia is a balanced trade partner with almost all countries in the world, and geographically, Saudi Arabia is an important link between Asia, Africa, and Europe. The factors making Saudi Arabia an attractive FDI-destination are: firstly, it has the largest market size among the GCC countries, attracting MNCs looking for scale. Secondly, infrastructure is relatively well developed and was globally ranked at 34 in 2019, and the country is continuously investing in infrastructure projects to create world-class infrastructure in the country. Thirdly, ICT adoption is improving 
in Saudi Arabia and globally is ranked 38 in 2019. The country was also becoming innovation-friendly and was ranked 36 in 2019. Fourthly, the financial system of Saudi Arabia is showing signs of improvement since 2018, and the banking system is well-capitalized and liquid. However, more improvements and technological upgrades are required to boost the efficiency of the financial system. Fifthly, Saudi Arabia features one of the lowest tax rates in the world, with no individual income tax scheme in the country. Sixthly, the Kingdom has a high degree of political stability, with low transfer risk, expropriation risk, and low levels of corruption. Seventhly, it has a stable currency that is pegged to the US dollar. The weaklings are: labour market efficiency was relatively low at rank 89 in 2019, efforts are required to increase the labour market efficiency. The current policy shift and the large young population will definitely contribute to enhancing the labour market efficiency in the near future. Further, Saudi Arabia has one the lowest rank in ease of doing business rankings and has to improve on many parameters to make it easy to do business in the country and attract FDI.

The limitation of this study is that the impact of the current Novel Coronavirus COVID-19 is not factored into the study, as it is still an ongoing pandemic; hence the investors are requested to factor in that while making the investment decisions.

\section{REFERENCES}

Alguacil, M., Cuadros, A., \& Orts, V. (2002). Foreign direct investment, exports, and domestic performance in Mexico: A causality analysis. Economic Letters, 77(1), 371-376. Retrieved from https://doi.org/10.1016/S01651765(02)00150-7

Al Hosani, M., Al Mahri, A., \& Fernandez, M. (2021). Analysis of Foreign Direct Investment Environment in Malaysia. The International Journal of Business Management and Technology, 5(1), 63-77.

Alnuaimi, H., Abdulla, E.S., \& Fernandez, M. (2021). Examination of Foreign Direct Investment Climate in Bahrain. International Journal of Economics, Commerce and Management, 9(2), 212-223.

Alshamlan, M. A., Fernandez, V. M., \& Fernandez, M. (2021). Foreign Direct Investment in the United Arab Emirates: A Study on the Main Contributors. European Journal of Business and Management Research, 6(1), 97-101. Retrieved from https://doi.org/10.24018/ejbmr.2021.6.1.694

Balasubramanyam, V. N., Salisu, M., \& Sapsford, D. (1996). Foreign direct investment and growth in EP and IS countries. Economic Journal, 106(1), 92-105. Retrieved from https://doi.org/10.2307/2234933

Billington, N. (1999). The location of foreign direct investment: an empirical analysis. Applied Economics, Vol. 31, pp. 65-76. Retrieved from https://doi.org/10.1080/00036846.2019.12067087

Boateng, A., Hua, X., Nisar, S., \& Wu, J. (2015). Examining the determinants of inward FDI: Evidence from Norway. Economic Modelling, 47, 118-127. Retrieved from https://doi.org/10.1016/j.econmod.2015.02.018

Bouchoucha, N., \& Benammou, S. (2020). Does institutional quality matter foreign direct investment? Evidence from African countries. Journal of the Knowledge Economy, 11(1), 390-404. Retrieved from https://doi.org/10.1007/s13132-018-0552-y

Brakman, S., \& Garretsen, H. (Eds.). (2008). Foreign direct investment and the multinational enterprise. MIT Press. Retrieved from https://doi.org/10.7551/mitpress/9780262026451.001.0001 
Caves, Richard. E. (1971). International Corporations: The Industrial Economics of Foreign Investment. Economica, 35(141), 1-27. Retrieved from https://doi.org/10.2307/2551748

Chandalert, A. (2000). The Determinants of U.S. Direct Investment in Thailand: A Survey on Managerial Perspectives. Multinational Business Review, 8(2), 82-88. Retrieved from https://www.elibrary.ru/item.asp?id=6079420

Cho, J. W. (2003). Foreign direct investment: determinants, trends in flows and promotion policies. Investment Promotion and Enterprise Development Bulletin for Asia and the Pacific, 1, 99-112. Retrieved from http://citeseerx.ist.psu.edu/viewdoc/download?doi=10.1.1.558.2969\&rep $=$ rep $1 \&$ type $=$ pdf

Credendo Group index reports. (2019). Available: Retrieved from https://www.credendo.com/country-risk

Culem, C.G. (1988). The locational determinants of direct investments among industrialized countries. European Economic Review, 32, 885-904. Retrieved from https://doi.org/10.1016/0014-2921(88)90051-7

De Mello, L. Jr. (1997). Foreign Direct Investment in Developing Countries and Growth: A Selective Survey. Journal of Development Studies, 34, 1-34. Retrieved from https://doi.org/10.1080/00220389708422501

Doing Business Global Ranking (2019). World Bank Group. Retrieved from http://www.doingbusiness.org/rankings.

Dunning, J.H. (1980). Toward an eclectic theory of international production : some empirical tests. Journal of International Business Studies, 11, 9-31. Retrieved from https://doi.org/10.1057/palgrave.jibs.8490593

Fernandez, M., Almaazmi, M. M., \& Joseph, R. (2020). Foreign Direct Investment in Indonesia: An Analysis from Investors Perspective. International Journal of Economics and Financial Issues, 10(5), 102-112. Retrieved from https://doi.org/10.32479/ijefi.10330

Fernandez, M., Shubaisi, A. M., \& Joseph, R. (2020). Examination of potentialities of Vietnam a FDI destination. Journal of Economics and Business, 3(3), 980994. Retrieved from https://doi.org/10.31014/aior.1992.03.03.254

Global Competitiveness Report (2019). Retrieved from https://www.weforum.org/reports/how-to-end-a- decade-of-lost productivity-growth .

Hajkova, D., Nicoletti, G., Vartia, L., \& Yoo, K. Y. (2006). Taxation and business environment as drivers of foreign direct investment in OECD Countries. OECD Economic Studies, 1(1), 7-38. Retrieved from https://doi.org/10.1787/eco_studies-v2006-art8-en

Kravis, I. \& Lipesey, R. (1982). The location of overseas production and production for export by US Multinational firms. Journal of International Economics, 12(3), 201-23. Retrieved from https://doi.org/10.1016/00221996(82)90036-8

Liu, X., Burridge, P., \& Sinclair, P. J. (2002). Relationships between economic growth, foreign direct investment, and trade: Evidence from China. Applied Economics, 34(1), 1433-1440. Retrieved from https://doi.org/10.1080/00036840110100835

Loree, D. W., \& Guisinger, S. E. (1995). Policy and non-policy determinants of U.S. equity foreign direct investment. Journal of International Business Studies, 26(2), 281-299. Retrieved from https://doi.org/10.1057/palgrave.jibs.8490174 
Lunn, J. (1980). Determinants of US direct investment in the EEC: further evidence. European Economic Review, 13(1), 93-101. Retrieved from https://doi.org/10.1016/0014-2921(80)90048-3

Makki, S.S., Somwaru, A. \& Bolling, C. (2004). Determinants of foreign direct investment in the food-processing industry: a comparative analysis of developed and developing economies. Journal of Food Distribution Research, 35(3), 60-7.

Milner, H. V. (2013). The Regime for International Investment: Foreign Direct Investment, Bilateral Investment Treaties, and Trade Agreements.

Mutti, J., \& Grubert, H. (2004). Empirical asymmetries in foreign direct investment and taxation. Journal of International Economics, 62(2), 337-358. Retrieved from https://doi.org/10.1016/S0022-1996(03)00016-3

Nigh, D. (1985). The effect of political events on United States direct foreign investment: A pooled time-series cross-sectional analysis. Journal of International Business Studies, 16(1), 1-17. Retrieved from https://doi.org/10.1057/palgrave.jibs.8490439

OECD. (2000). Main determinants of FDI and its impact of foreign direct investment on China's economy. working papers on international investment no. 4, prepared for OECD cooperation programme.

Osunkwo, F. O. (2020). Foreign Direct Investment and Economic Growth of Nigeria (1980-2018). Journal of Economics and Business, 3(1). Retrieved from https://doi.org/10.31014/aior.1992.03.01.206

Pistoresi, B. (2000). Investimenti Diretti Esteri e Fattori di Localizzazione: L'America Latina e il SudEst Asiatico. Rivista di Politica Economica, 90, 2744.

Retrieved

from https://iris.unimore.it/handle/11380/609000\#.YTnnLp0zbIU

Reiljan, E. (2003). Analysis of foreign direct investment determinants in Estonia. Journal of East-West Business, 8(3-4), 103-121. Retrieved from https://doi.org/10.1300/J097v08n03_07

Root, F. R., \& Ahmed, A. A. (1979). Empirical determinants of manufacturing direct foreign investment in developing countries. Economic development and cultural change, 27(4), 751-767. Retrieved from https://doi.org/10.1086/451139

Saudi Central Bank (SAMA). Retrieved from https://www.sama.gov.sa/enUS/pages/default.aspx

Schmitz, A., \& Bieri, J. (1972). EEC tariffs and US direct investment. European Economic Review, 3(3), 259- 270. Retrieved from https://doi.org/10.1016/0014-2921(72)90007-4

Schneider, F., \& Frey, B. S. (1985). Economic and political determinants of foreign direct investment. World development, 13(2), 161-175. Retrieved from https://doi.org/10.1016/0305-750X(85)90002-6

Transparency International, the Corruption Perceptions Index (2019). Retrieved from http://www.transparency.org

Tsai, P. (1994). Determinants of foreign direct investment and its impact on economic growth. Journal of Economic Development, 19(1), 137-163. Retrieved from http://www.jed.or.kr/full-text/19-1/6.pdf

Zhao, H. \& Zhu, G. (2000). Location factors and country-of-origin differences: An empirical analysis of FDI in China. Multinational Business Review, 8(1), 6073. Retrieved from https://www.elibrary.ru/item.asp?id=6080210 